\title{
Pembelajaran Operasi Penjumlahan dan Pengurangan Bilangan Bulat Menggunakan Garis Bilangan
}

\author{
${ }^{1}$ Irianto Aras, Hermansyah, Jero Budi Darmayasa \\ Program Studi Pendidikan Matematika, Universitas Borneo Tarakan \\ Jl. Amal Lama No.01, Tarakan, Indonesia \\ Email: ${ }^{1}$ arasirianto1990@gmail.com
}

Article History:

Received: 13-05-2020; Received in Revised: 18-02-2021; Accepted: 20-02-2021

\begin{abstract}
This study aims at determining the role of the number line media in helping students understand and obtain local instructional theory in learning integer operations in the 4th Grade of Madrasah Ibtidaiyah in Tarakan. This research is design with three stages, namely preliminary design, experimental design, and retrospective analysis. In the preliminary design stage, a number line media along with the hypothetical learning trajectory is made. Then the teaching experiment is conducted to compare the expected learning trajectory with the actual learning trajectory that takes place. In the final stage, a retrospective analysis is carried out by viewing the video recording of learning and evaluation results. From the analysis, it was found that the use of number lines can help students to understand the operations of addition and subtraction of integers. This study also developed local instructional theory related to learning integers using number lines.
\end{abstract}

Keywords: Integers; Learning Trajectory; Number Lines.

\begin{abstract}
Abstrak
Penelitian ini bertujuan untuk mengetahui peranan media garis bilangan dalam membantu pemahaman siswa serta mengembangkan teori instruksional lokal (local intructional theory) pada pembelajaran operasi bilangan bulat di kelas IV di salah satu Madrasah Ibtidaiyah di Kota Tarakan. Desain penelitian ini terdiri dari tiga tahap, yaitu desain pendahuluan, desain percobaan, dan analisis retrospektif. Pada tahap desain pendahuluan dilakukan pembuatan media garis bilangan beserta dugaan lintasan belajar, kemudian dilakukan percobaan pengajaran untuk membandingkan lintasan belajar yang diharapkan dengan lintasan belajar yang sesungguhnya terjadi. Pada tahap akhir dilakukan analisis retrospektif dengan melihat rekaman video pembelajaran dan hasil evaluasi. Dari analisis tersebut ditemui bahwa penggunaan garis bilangan dapat membantu siswa untuk memahami operasi penjumlahan dan pengurangan bilangan bulat. Penelitian ini juga mengembangkan teori instruksional lokal terkait pembelajaran bilangan bulat menggunakan garis bilangan.
\end{abstract}

Kata Kunci: Bilangan Bulat; Lintasan Belajar; Garis Bilangan. 


\section{Pendahuluan}

Matematika merupakan ilmu pengetahuan mendasar yang mesti diberikan kepada peserta didik untuk mengantarkan mereka ke pemikiran logis, kreatif, cermat, efisien, dan solutifi. Tujuan pendidikan matematika di Sekolah Dasar merupakan bekal awal siswa mempelajari materi matematika di Sekolah Menengah ${ }^{2}$. Ini berarti materi yang diberikan memiliki tingkatan abstrak yang lebih rendah ketimbang definisi matematika pada tingkat menengah dan definisi matematika sebagai suatu ilmu. Sebagai ilmu matematika adalah ilmu yang bersifat abstrak dan berpola pikir deduktif, maka pada tingkat Sekolah Dasar pola pembelajaran mesti dimulai dari pembelajaran yang bersifat induktif dan konkret. Bahkan harus dikaitkan dengan realitas keseharian siswa, sebab matematika memiliki konsep yang abstrak sementara siswa Sekolah Dasar masih pada tahap berpikir konkret ${ }^{3}$. Tugas inilah yang menjadi tuntutan guru untuk mengatasi sifat abstrak dari konsep-konsep matematika tersebut. Artinya, setiap guru harus mampu berinovasi dalam proses belajar mengajar, sehingga pembelajaran yang dihasilkan sesuai dengan perkembangan pendidikan ${ }^{4}$.

Materi pokok bagi matematika di Sekolah Dasar adalah pengenalan bilangan bulat dan operasinya ${ }^{5}$. Berdasarkan tes awal yang dilakukan di salah satu Madrasah Ibtidaiyah di Kota Tarakan, ditemui kesalahan siswa dalam melakukan penjumlahan dan pengurangan pada bilangan bulat sebagai berikut, yaitu:

1) Kesalahan dalam melakukan penjumlahan.

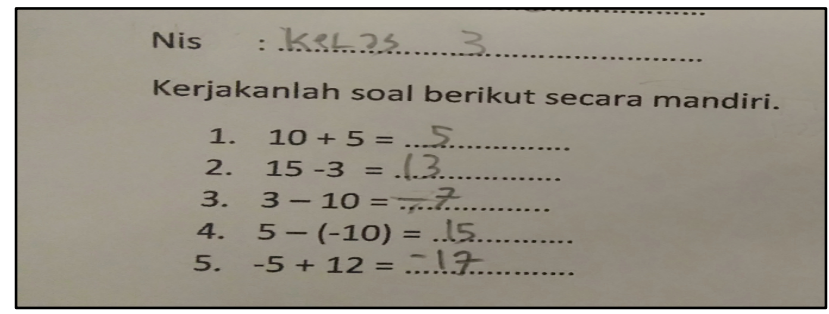

Gambar 1. Kesalahan Melakukan Penjumlahan

1 Irianto Aras, "Pengembangan Desain Pembelajaran Matematika Berbasis Teori Elaborasi Dengan Pendekatan Saintifik Pada Siswa Kelas X7 Madrasah Aliyah Negeri Pinrang" (masters, Pascasarjana, 2014), http://eprints.unm.ac.id/4723/.

2 Gatot Muhsetyo, “Pembelajaran Matematika SD," Jakarta: Universitas Terbuka, 2009.

3 Muslimin Muslimin, Ratu Ilma Indra Putri, and Somakim Somakim, "Desain Pembelajaran Pengurangan Bilangan Bulat Melalui Permainan Tradisional Congklak Berbasis Pendidikan Matematika Realistik Indonesia Di Kelas IV Sekolah Dasar," Kreano, Jurnal Matematika Kreatif-Inovatif 3, no. 2 (December 1, 2012): 100-112, https://doi.org/10.15294/kreano.v3i2.2642.

4 Rully Prahmana, "Pendesainan Pembelajaran Operasi Bilangan Menggunakan Permainan Tradisional Tepuk Bergambar Untuk Siswa Kelas III Sekolah Dasar (SD)" (2012), https://doi.org/10.13140/RG.2.2.33884.59529.

5 Sutrisno Sutrisno, "Analisis Kesulitan Belajar Siswa Kelas Ii Pada Materi Penjumlahan Dan Pengurangan Bilangan," AKSIOMA : Jurnal Matematika Dan Pendidikan Matematika 6, no. 1/Maret (2015), https://doi.org/10.26877/aks.v6i1/Maret.862. 
Siswa gagal melakukan penjumlahan sederhana tentang "10 +5 ", ada beberapa siswa yang menjawab 6, kesalahan siswa melakukan penjumlahan diduga karena siswa bersangkutan belum memahami tentang bilangan bulat positif dan operasi penjumlahannya.

2) Kesalahan dalam melakukan penjumlahan bilangan negativ

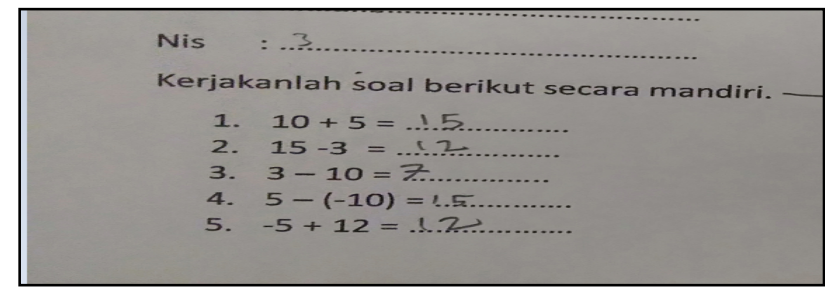

Gambar 2. Kesalahan Melakukan Penjumlahan Bilangan Negatif

Dari Gambar 2 terlihat siswa gagal melakukan penjumlahan sederhana tentang "-5 + 12", ada beberapa siswa yang menjawab 12 , kesalahan siswa melakukan penjumlahan diduga karena mereka tidak memahami bahwa "$5+12$ " itu setara dengan " $12-5$ ".

Dari kesalahan tersebut, terlihat bahwa siswa masih sulit dalam menyelesaikan operasi penjumlahan maupun pengurangan bilangan bulat, terlebih jika operasi yang diberikan memuat atau menghasilkan bilangan negatif. Bagaimana tidak, bilangan negatif tidak seperti bilangan asli, bilangan negatif tidak memiliki referensi fisik secara alami sehingga otak kesulitan merepresentasikan konsep matematika abstrak seperti itu6 ${ }^{6}$ Kesulitan serupa bahkan tidak hanya terjadi di tingkat sekolah dasar, berbagai penelitian juga menunjukkan bahwa bilangan negatif memberikan berbagai persoalan sendiri bagi banyak siswa di sekolah menengah7.

Pembelajaran bilangan bulat di tingkat SD/MI perlu menjadi perhatian, sebab pengetahuan tentang bilangan menjadi acuan untuk mendukung pemikiran dan pemahaman anak untuk menyelesaikan masalah mereka ${ }^{8}$. Untuk mengatasi hal tersebut, maka perlu digunakan media pembelajaran yang tepat, sebab melalui media pembelajaran anak akan lebih menghayati

\footnotetext{
${ }^{6}$ Kristen Pilner Blair et al., "Beyond Natural Numbers: Negative Number Representation in Parietal Cortex," Frontiers in Human Neuroscience 6 (2012), https://doi.org/10.3389/fnhum.2012.00007.

7 Rut Almeida and Alicia Bruno, "Strategies of Pre-Service Primary School Teachers for Solving Addition Problems with Negative Numbers," International Journal of Mathematical Education in Science and Technology 45, no. 5 (July 4, 2014): 719-37, https://doi.org/10.1080/0020739X.2013.877605.

8 Carol W. Midgett and Susan K. Eddins, Special Section Math and Science Education Nctm's Principles and Standards for School Mathematics: Implications for Administrators, n.d.
} 
matematika secara nyata berdasarkan fakta yang jelas dan dapat dilihatnya ${ }^{9}$. Media yang dimaksud adalah garis bilangan, garis bilangan adalah media yang efektif namun jarang digunakan untuk mengembangkan pengetahuan siswad $^{10}$

Penggunaan media garis/mistar bilangan berpengaruh secara signifikan terhadap pemahaman penjumlahan bilangan bulat matematika siswa tingkat SD di Malang11. Lebih lanjut, penggunaan media garis bilangan berhasil meningkatkan hasil belajar matematika ${ }^{12}$ dan kemampuan berhitung bilangan bulat siswa tingkat $\mathrm{SD}^{13}$. Namun demikian perlu disadari bahwa perencanaan pembelajaran terkadang meleset jauh dari proses pelaksanaannya di kelas dan sewaktu-waktu dapat berubah (dinamis). Untuk itu, perlu dilakukan studi yang fokus pada serangkaian kegiatan pembelajaran terkait bagaimana garis bilangan dapat membantu pemahaman siswa dalam memahami operasi penjumlahan dan pengurangan bilangan bulat. Selain itu, lintasan pembelajaran yang selama ini ditetapkan mengikuti teori secara kaku dapat dikembangkan dan disesuaikan dengan keadaan awal sehingga ditemukan teori instruksional lokal yang sesuai.

Clements \& Sarama mendefinisikan lintasan belajar (learning trajectory) sebagai deskripsi pemikiran siswa dalam belajar matematika pada domain tertentu berupa rute dugaan belajar melalui serangkaian tugas instruksional, dimana proses atau tindakan yang dihipotesiskan dapat mengantar pemahaman anak melalui perkembangan tingkat pemikiran untuk mencapai tujuan belajaranya ${ }^{14}$. Beberapa penelitian yang melibatkan dugaan lintasan belajar telah berhasil membantu pemahaman siswa, seperti pada

9 Almira Amir, "Pembelajaran Matematika SD Dengan Menggunakan Media $\begin{array}{lllll}\text { Manipulatif," Forum } & \text { Paedagogik no. } & \text { 6, 2014), }\end{array}$ https://doi.org/10.24952/paedagogik.v6i01.166.

${ }^{10}$ Nancy I. Dyson et al., "A Fraction Sense Intervention for Sixth Graders With or At Risk for Mathematics Difficulties," Remedial and Special Education 41, no. 4 (July 1, 2020): 244-54, https://doi.org/10.1177/0741932518807139.

11 Nikmatus Sukrila, "Pengaruh Media Mistar Bilangan Terhadap Pemahaman Penjumlahan Bilangan Bulat Matematika Kelas IV MI Imami Kepanjen Malang” (PhD Thesis, Universitas Islam Negeri Maulana Malik Ibrahim, 2015).

12 Indah Syilvia Santoso, "Penggunaan Media Garis Bilangan Untukmeningkatkan Hasil Belajar Operasi Penjumlahan Dan Pengurangan Bilangan Bulat," Jurnal Penelitian Pendidikan Guru Sekolah Dasar 2, no. 3 (2014): 1-10.

13 Elfi Lailan Syamita Lubis, "Penggunaan Media Garis Bilangan Untuk Meningkatkan Kemampuan Berhitung Bilangan Bulat Pada Siswa Kelas IV MIS Nurul Hasanah Lubuk Pakam Tahun Pelajaran 2016/2017" (Seminar Nasional Matematika (SEMNASTIKA), Medan: Universitas Negeri Medan, 2017).

14 Phil Daro, Frederic A. Mosher, and Tom Corcoran, Learning Trajectories in Mathematics: A Foundation for Standards, Curriculum, Assessment, and Instruction. CPRE Research Report \# RR-68, Consortium for Policy Research in Education (Consortium for Policy Research in Education, 2011), https://eric.ed.gov/?id=ED519792. 
pembelajaran pecahan ${ }^{15}$. Begitupula dengan pembelajaran operasi bilangan bulat menggunakan permainan tepuk bergambar ${ }^{16}$. Inovasi dalam pembelajaran matematika memang dibutuhkan untuk melakukan perbaikan terhadap kegiatan pembelajaran, inovasi tersebut merujuk pada penggunaan konteks sebagai starting point dalam proses pembelajaran ${ }^{17}$. Untuk itu, penelitian ini mengkaji tentang pembelajaran operasi penjumlahan dan pengurangan bilangan bulat menggunakan media garis bilangan pada siswa kelas IV di salah satu Madrasah Ibtidaiyah di Kota Tarakan. Penelitian ini bertujuan untuk mengetahui peranan media garis bilangan dalam membantu pemahaman siswa serta mengembangkan teori instruksional lokal (local intructional theory) pada pembelajaran operasi bilangan bulat di kelas IV di salah satu Madrasah Ibtidaiyah di Kota Tarakan.

\section{Metode}

Metode penelitian yang digunakan dalam penelitian ini adalah penelitian desain (design research) yang mencoba melakukan peningkatan kualitas pembelajaran di kelas melalui analisis interaktif dari dugaan tentang apa yang akan terjadi di dalam kelas beserta implementasinya ${ }^{18}$. Peningkatan kualitas pembelajaran dilakukan melalui pengembangan Local Intructions Theory ${ }^{19}$. Penelitian ini bertujuan untuk mengetahui peranan media garis bilangan dalam membantu pemahaman siswa serta memperoleh teori instruksional lokal (local intructional theory) pada pembelajaran operasi bilangan bulat. Subjek pada penelitian ini adalah siswa kelas IV di salah satu Madrasah Ibtidaiyah di Kota Tarakan yang berjumlah 16 orang. Kelas tersebut dipilih berdasarkan tes awal yang diberikan pada akhir semester genap ketika subjek masih berada di kelas III.

Tahapan dalam penelitian ini mengikuti tahapan design research yaitu sebagai berikut: ${ }^{20}$

15 Mewa Zabeta, Yusuf Hartono, and Ratu Ilma Indra Putri, "Desain Pembelajaran Materi Pecahan Menggunakan Pendekatan Pendidikan Matematika Realistik Indonesia (PMRI)," Beta: Jurnal Tadris Matematika 8, no. 1 (May 14, 2015): 86-99, https://jurnalbeta.ac.id/index.php/betaJTM/article/view/27.

16 Prahmana, "Pendesainan Pembelajaran Operasi Bilangan Menggunakan Permainan Tradisional Tepuk Bergambar Untuk Siswa Kelas III Sekolah Dasar (SD).” 2017.

17 Rully Prahmana, Design Research (Teori Dan Implementasinya: Suatu Pengantar),

18 Jan Van Den Akker, ed., Educational Design Research, 1st edition (London ; New York: Routledge, 2006).

19 Koeno Gravemeijer and Dolly van Eerde, "Design Research as a Means for Building a Knowledge Base for Teachers and Teaching in Mathematics Education," Elementary School Journal109, no. 5 (May 2009): 510-24, https://doi.org/10.1086/596999.

20 Prahmana, Design Research (Teori Dan Implementasinya. 
1. Tahap I: Preliminary Design (Desain Pendahuluan)

Pada desain pendahuluan dilakukan kajian literatur mengenai materi operasi penjumlahan dan pengurangan bilangan bulat menggunakan garis bilangan untuk mengembangkan kegiatan pembelajaran dan instrumen evaluasi. Dari proses pengkajian dibuatlah lintasan belajar dan dugaan berpikir siswa (konjektur) sebagai pedoman pada aktivitas pembelajaran yang sewaktu-waktu dapat direvisi pada tahap percobaan.

\section{Tahap II: Design Experiment (Desain Percobaan)}

Pada tahap desain percobaan, lintasan pembelajaran yang telah dibuat diujicobakan terlebih dahulu dalam proses pembelajaran. Tujuannya adalah melakukan pendalaman dan menduga rencana serta pemikiran siswa pada kegiatan pembelajaran yang sesungguhnya.

3. Tahap III: Restrospective Analysis (Analisis Restrospektif)

Pada tahap ini, dugaan berpikir siswa (konjektur) dalam HLT dibandingkan dengan tahapan yang ditemui pada desain percobaan. Sehingga, hasil analisis ini dapat memberikan deskripsi mengenai lintasan belajar dalam pembelajaran operasi penjumlahan dan pengurangan bilangan bulat menggunakan media garis bilangan. Untuk mengumpulkan data dalam penelitian ini, digunakan instrumen penelitian berupa tes hasil belajar per pertemuan dan lintasan belajar yang direkam melalui kamera selama kegiatan pembelajaran berlangsung, dengan tujuan memperoleh visualisasi terhadap penguasaan siswa terhadap operasi penjumlahan dan pengurangan bilangan bulat. Analisis data yang dilakukan dalam penelitian ini berupa analisis retrospektif bersama hypotethical learning trajectory sebagai pemandunya.

\section{Hasil dan Diskusi}

\section{Desain Pendahuluan (Preliminary Design)}

Pada tahap ini, peneliti menerapkan ide awal penggunaan media garis sebagai solusi terhadap permasalahan yang ditemui pada tes awal. Adapun media yang dibuat berupa banner garis bilangan seperti yang terlihat pada Gambar 3.

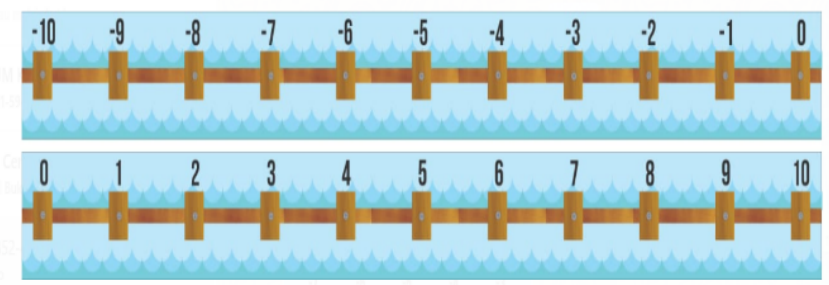

Gambar 3. Desain Garis Bilangan yang Akan Dicetak 
Selain media, peneliti juga membuat instrumen evaluasi dan dugaan lintasan belajar atau hypothetical learning trajectory(HLT). Instrumen berupa soal-soal singkat yang diberikan pada tiap pertemuan untuk dikerjakan secara kelompok maupun individu. Sementara itu, HLT berisi tentang aktivitas yang akan dilalui siswa dalam pembelajaran yang terdiri dari tiga aktivitas, yaitu: (1) menggunakan garis bilangan dalam penjumlahan dan pengurangan bilangan bulat positif, (2) menggunakan garis bilangan dalam mengoperasikan penjumlahan bilangan bulat negatif, dan (3) menggunakan garis bilangan dalam mengoperasikan penjumlahan dan bilangan bulat positif terhadap negatif dan sebaliknya.

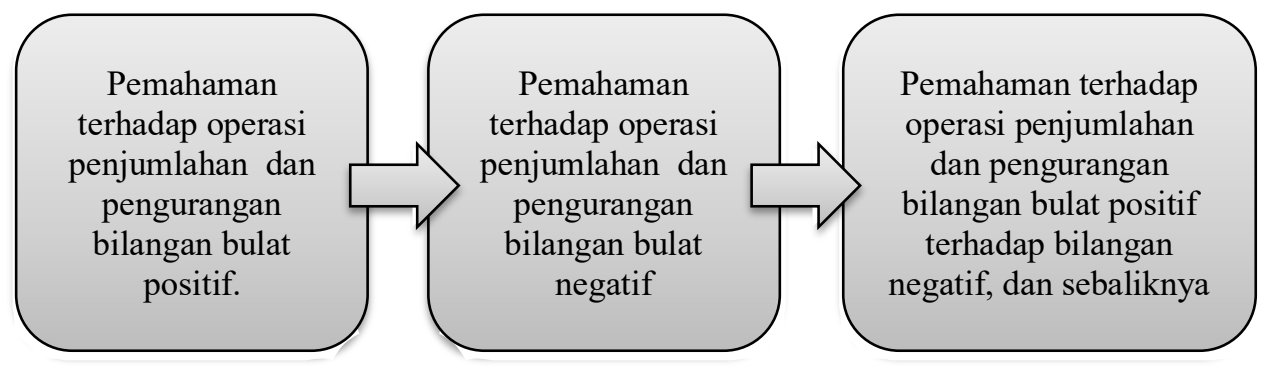

Gambar 4. Learning Trajectory

Selain lintasan belajar, peranan media garis bilangan dalam membangun pemahaman siswa tentang operasi penjumlahan dan pengurangan bilangan bulat juga dilihat. Kegiatan ini bertujuan untuk mengantarkan siswa dari pemahaman yang bersifat konkret ke pemahaman yang bersifat abstrak (formal/semi formal). Dugaan berpikir siswa untuk aktivitas satu dapat dilihat pada Tabel 1, sementara untuk aktivitas lainnya tidak jauh berbeda dari dugaan aktivitas satu.

Tabel 1. Dugaan Berpikir Siswa

\begin{tabular}{ll}
\hline Kegiatan & \multicolumn{1}{c}{ Dugaan Berpikir Siswa } \\
\hline $\begin{array}{l}\text { Menghamparkan garis } \\
\text { bilangan dan bertanya } \\
\text { kepada siswa tentang } \\
\begin{array}{l}\text { pernahkah sebelumnya } \\
\text { melihat garis bilangan. }\end{array}\end{array}$ & $\begin{array}{l}\text { Terdapat siswa yang mengetahui letak } \\
\text { bilangan bulat positif dan negatif, sebagian } \\
\text { siswa mengetahui yang positif saja, sebagian } \\
\text { siswa baru melihat garis bilangan dan } \\
\text { bimana letak bilangan bulat } \\
\text { positif dan negatif pada } \\
\text { garis bilangan? }\end{array}$ \\
\hline $\begin{array}{l}\text { Mendemonstrasikan } \\
\text { penggunaan garis bilangan } \\
\text { pada operasi penjumlahan }\end{array}$ & Saris bilangan untuk mengetahui hasil \\
\hline
\end{tabular}




\begin{tabular}{|c|c|}
\hline Kegiatan & Dugaan Berpikir Siswa \\
\hline $\begin{array}{l}\text { dan pengurangan bilangan } \\
\text { bulat }\end{array}$ & $\begin{array}{l}\text { i penjumlahan dan pengurangan } \\
\text { an bulat. }\end{array}$ \\
\hline $\begin{array}{l}\text { Memberikan soal latihan } \\
\text { untuk dikerjakan secara } \\
\text { berkelompok dengan } \\
\text { bergantian menggunakan } \\
\text { garis bilangan }\end{array}$ & $\begin{array}{l}\text { Melalui aktivitas secara berkelompok siswa } \\
\text { dapat menentukan hasil operasi } \\
\text { penjumlahan dan pengurangan bilangan } \\
\text { bulat secara tepat. Perkiraan lain beberapa } \\
\text { siswa masih kebingungan sehingga perlu } \\
\text { bimbingan guru dalam menggunakan garis } \\
\text { bilangan }\end{array}$ \\
\hline $\begin{array}{l}\text { dap operikan penguatan } \\
\text { mlahan dan } \\
\text { drangan. Terutama } \\
\text { operasi yang setara, } \\
\text { nya } 2+3=2-(-3)\end{array}$ & $\begin{array}{l}\text { Untuk operasi penjumlahan mereka tidak } \\
\text { akan menemui kesulitan, yang mungkin sulit } \\
\text { adalah pengurangan terhadap bilangan } \\
\text { negatif, dan pengurangan dua bilangan } \\
\text { positif yang menghasilkan bilangan negatif. }\end{array}$ \\
\hline $\begin{array}{l}\text { Memberikan tugas individu } \\
\text { terkait operasi penjumlahan } \\
\text { dan pengurangan bilangan } \\
\text { bulat }\end{array}$ & $\begin{array}{l}\text { Siswa dapat menyelesaikan soal terkait } \\
\text { operasi penjumlahan dan pengurangan } \\
\text { bilangan negatif tanpa bantuan garis } \\
\text { bilangan. }\end{array}$ \\
\hline
\end{tabular}

\section{Percobaan Pengajaran (Teaching Experiment)}

Percobaan pengajaran dilakukan sebanyak tiga kali pertemuan dengan alasan bahwa bilangan negatif membutuhkan waktu yang lebih lama untuk dijelaskan. Kegiatan pembelajaran yang dilakukan mengikuti lintasan belajar yang telah dibuat. Sebelum diterapkan, garis bilangan beserta prosedur penggunaannya terlebih dahulu diuji coba pada beberapa siswa oleh guru bersangkutan. Dalam percobaan pengajaran ini, guru siswa sendiri yang bertindak sebagai pengajar, sementara peneliti sebagai observer pada aktivitas pembelajaran.

\subsection{Pertemuan 1}

Aktivitas pada pertemuan satu adalah menggunakan garis bilangan untuk memahami konsep penjumlahan dan pengurangan bilangan positif. Materi pelajaran yang diberikan sebagai starting point adalah operasi penjumlahan dan pengurangan bilangan bulat. Di awal pertemuan guru membuka pelajaran dan menyampaikan tujuan pembelajaran, kemudian melakukan wawancara kepada siswa untuk melihat kemampuan awal siswa. Guru membuat garis bilangan (tanpa angka) pada papan tulis, kemudian melakukan tanya jawab kepada siswa untuk menentukan letak bilangan bulat pada garis bilangan. 
Guru: "Letak bilangan 5 ada dimana"

Amin: "Itu bu, pada garis kelima gambar yang ibu buat"

Guru: "Ada jawaban yang lain selain jawaban Amin?"

Siswa: "Sama bu"

Guru: "Kalau sama, ayo ibu coba dengan pertanyaan lain, bisa ndag!"

Guru kemudian melanjutkan dengan menanyakan letak bilangan lain pada garis bilangan, dari tanya-jawab terlihat bahwa umumnya siswa telah mengetahui letak masing-masing angka pada garis bilangan. Garis bilangan yang telah dicetak kemudian diperkenalkan kepada siswa, aturan main pada bagian ini adalah positif diberi arti maju, bilangan negatif diberi arti mundur, ditambah berarti jalan terus, dan dikurang berarti balik kanan. Aturan main tersebut didemonstrasikan oleh guru dengan memberikan contoh penerapan garis bilangan dengan operasi: $2+4$ dan $4-2$.

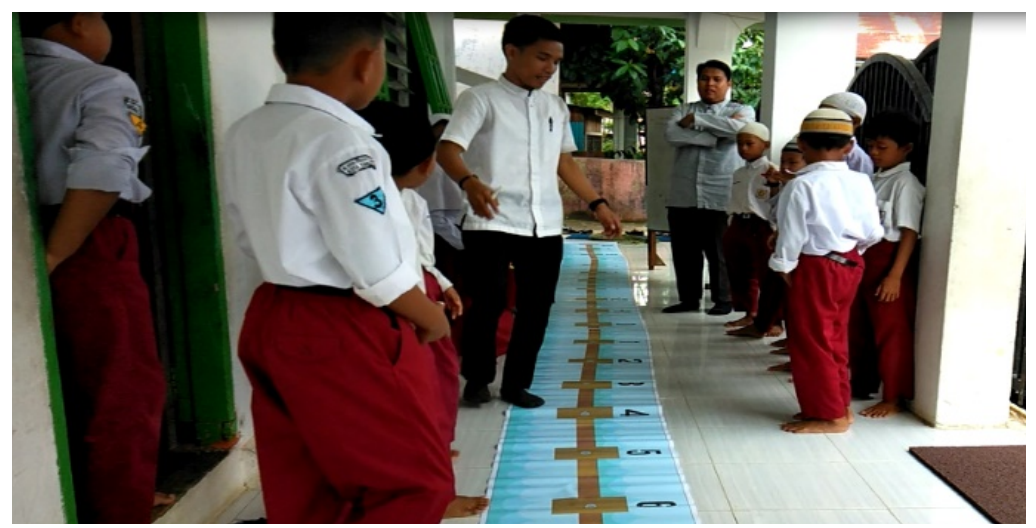

Gambar 5. Demonstrasi Penggunaan Garis Bilangan

Setelah pemberian demonstrasi selesai, siswa kemudian diarahkan untuk mengerjakan soal secara berkelompok, pada tahap ini masing-masing kelompok boleh menggunakan garis bilangan untuk menyelesaikan soal yang diberikan. Hasil pengerjaan kelompok didiskusikan bersama untuk melihat apakah jawaban yang mereka peroleh sudah benar atau tidak, jika belum benar, maka siswa diarahkan untuk menyelesaikan ulang dengan mempraktikan pada garis bilangan. Kegiatan kemudian dilanjutkan dengan pemberian soal untuk dikerjakan secara individu untuk melihat bagaimana pemahaman siswa tentang operasi penjumlahan dan pengurangan bilangan bulat positif secara formal (semi formal).

\subsection{Pertemuan 2}

Penekanan aktivitas pada pertemuan dua adalah penggunaan garis bilangan untuk memahami operasi penjumlahan dan pengurangan bilangan bulat negatif. Lintasan belajar yang dilakukan umumnya seperti pada pertemuan pertama. Di awal pembelajaran guru menyampaikan tujuan 
pembelajaran dan melakukan apersepsi. Untuk memulai pembelajaran tentang bilangan bulat negatif, guru membuat garis bilangan dengan hanya menuliskan angka 0 dipertengahan garis bilangan. Guru kemudian mengajukan pertanyaan ke siswa tentang angka apa saja yang ada disebelah kanan angka 0.

Guru: "Perhatikan garis bilangan yang ibu buat, coba tebak angka apa saja yang berada disebelah kanan angka 0?"

Bintang: "Satu.. Dua.. Tiga..(dibantu siswa lainnya)"

Guru: "Bagus Bintang, sekarang angka apa saja yang ada disebelah kiri angka 0?"

Siswa: "Minus 1, Min 2, Min 3, dan seterusnya"

Guru: "Bagus, sekarang angka tersebut disebut bilangan apa?"

Beberapa siswa menjawab bilangan negatif, beberapa siswa lainnya terlihat diam dan bingung tentang bilangan negatif. Melihat kondisi tersebut, guru dan peneliti berdiskusi sejenak untuk segera merombak kegiatan pembelajaran yang telah dibuat dengan memberi penekanan pada pengenalan bilangan negatif. Melalui garis bilangan guru menjelaskan bahwa letak bilangan negatif pada garis bilangan berada disebelah kiri angka 0, jika pada bilangan positif semakin ke kanan nilainya semakin besar, maka pada bilangan negatif semakin ke kiri nilanya semakin kecil. Proses pengenalan ini terus berlanjut sampai siswa dianggap mampu untuk mempelajari operasi penjumlahan dan pengurangan bilangan negatif.

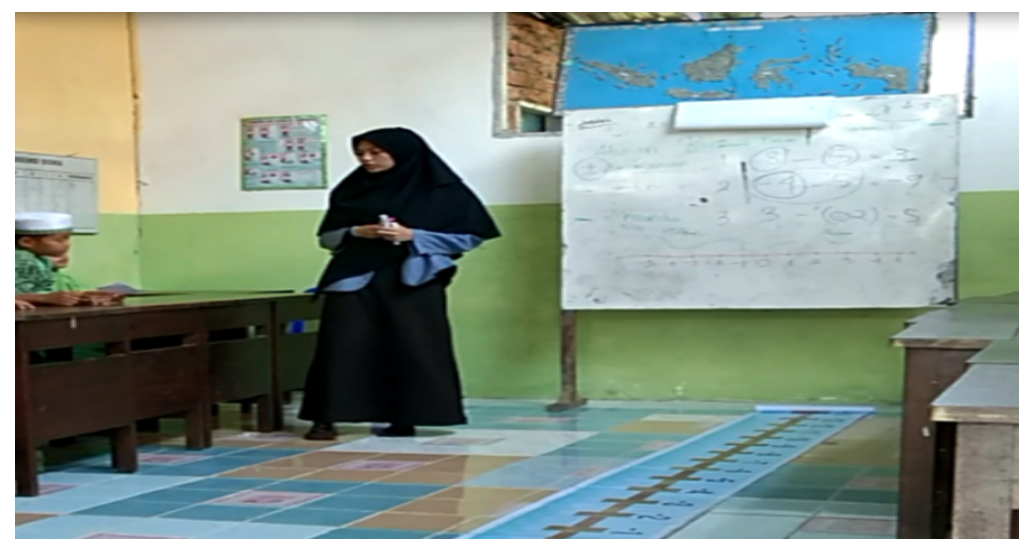

Gambar 6. Penjelasan Bilangan Negatif

Setelah siswa dianggap telah memahami bilangan bulat negatif, guru kemudian melanjutkan kegiatan pembelajaran dengan praktik menggunakan garis bilangan. Aturan penggunaan garis bilangan sedikit diubah dengan melihat kesulitan siswa jika harus berbalik atau jalan terus seperti pada aktivitas pertemuan satu. Pada tahap ini bilangan positif berarti ke kanan, 
bilangan negatif berarti ke kiri, penjumlahan berarti maju, dan pengurangan berarti mundur.

Setelah pemberian demonstrasi selesai, siswa kemudian diarahkan untuk mengerjakan soal secara berkelompok, dan dilanjutkan ke pemberian soal secara individu untuk mengecek pemahaman siswa.

\subsection{Pertemuan 3}

Pada pertemuan ketiga, materi pembelajaran yang dibahas adalah lanjutan dari aktivitas dua, yaitu operasi pengurangan dan penjumlahan bilangan bulat positif terhadap bilangan bulat negatif dan sebaliknya. Lintasan pembelajaran yang digunakan umumnya sama, hanya berbeda pada aktivitas penggunaan garis bilangan. Aturan main pada bagian ini adalah positif diberi arti maju, bilangan negatif diberi arti mundur, ditambah berarti hadap kanan, dan dikurang berarti hadap kiri.

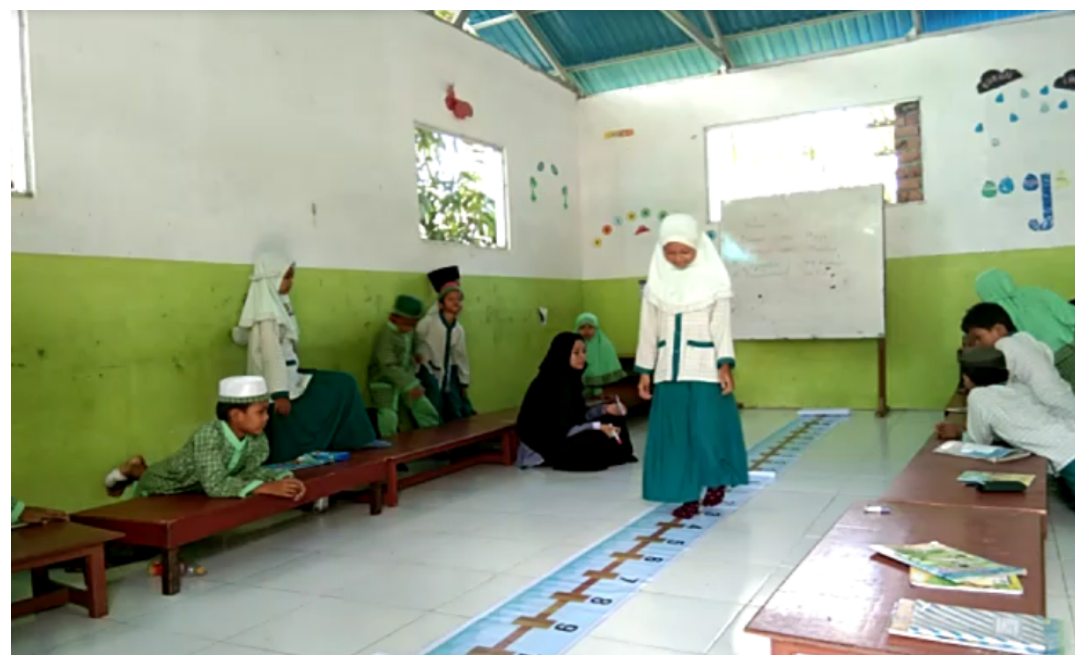

Gambar 7. Penggunaan Garis Bilangan Oleh Siswa

Setelah pemberian demonstrasi seperti yang terlihat pada Gambar 7 selesai, siswa kemudian diarahkan untuk mengerjakan soal secara berkelompok dan invidu sebagaimana lintasan pembelajaran yang dilakukan sebelumnya.

\section{Analisis Retrospektif}

Pada bagian ini, peneliti menjawab rumusan masalah yang diajukan berdasarkan analisis retrospektif bersama HLT yang merupakan pemandunya.

3.1. Garis bilangan untuk membangun pemahaman siswa terhadap operasi pengurangan dan penjumlahan bilangan bulat

Pemahaman siswa yang hendak dibangun adalah bagaimana memahami operasi penjumlahan dan pengurangan bilangan bulat menggunakan garis bilangan. Dari demonstrasi yang diberikan oleh guru tentang penggunaan 
media garis bilangan, tidak ditemui kendala pada penyelesaian latihan soal penjumlahan dan pengurangan bilangan bulat positif, ini disebabkan karena siswa telah mempunyai konsep awal dalam melakukan operasi tersebut, dengan kata lain peran media garis bilangan tidak begitu terlihat apakah terbangun dari penggunaan media ataukah karena pengetahuan awal mereka.

Pada aktivitas kedua tentang penggunaan media garis bilangan dalam operasi penjumlahan dan pengurangan bilangan negatif, peran media dalam membangun pemahaman siswa belum terlihat di awal penggunaan. Awalnya siswa kebingungan tentang hasil dari operasi pengurangan dua bilangan negatif seperti "-4 - 3", ini memang wajar sebab siswa masih kesulitan mengenali tanda minus sebagai operasi pengurangan dan sebagai lambang bilangan negatif. Hal ini sejalan dengan yang dikemukakan oleh Subanji bahwa terdapat kesalahan mengkonstruksi konsep operasi bilangan bulat yang menyamakan antara lambang bilangan dan operasi bilangan pada simbo "-“ (minus) ${ }^{21}$. Namun setelah dilakukan praktik menggunakan garis bilangan secara berulang untuk bilangan negati, terlihat siswa sudah dengan mudah menjawab dengan benar. Hasil kerja kelompok juga menunjukkan bahwa umumnya para siswa telah memahami konsep yang diberikan. Meski demikian, hasil kerja individu memberikan hasil yang sedikit berbeda, pemahaman siswa belum sepenuhnya berada pada tahap formal (semi formal), sebab mereka mampu menjawab dengan benar menggunakan garis bilangan, tetapi salah ketika mengerjakan soal tanpa bantuan garis bilangan.

Pada aktivitas tiga, penekanan konsep formal yang ingin dicapai menggunakan garis bilangan adalah operasi " $4-(-3)$ " sama dengan operasi 4 +3 , hasil kerja kelompok (menggunakan garis bilangan) menunjukkan bahwa siswa mampu menjawab dengan benar untuk setiap soal yang diberikan. Begitupun dengan hasil kerja individu, meski soalnya lebih kompleks, beberapa siswa dapat menyelesaikan dengan baik dan benar untuk setiap soal yang diberikan.
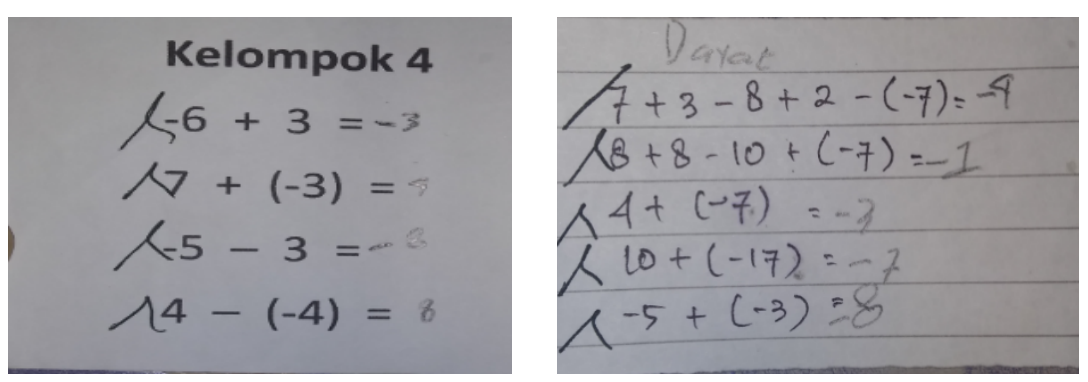

Gambar 8. Hasil Kerja Kelompok dan Individu

21 Subanji Subanji, Teori Kesalahan Konstruksi Konsep Dan Pemecahan Masalah Matematika, 2015. 
3.2. Lintasan belajar operasi penjumlahan dan pengurangan bilangan bulat

Lintasan belajar yang digunakan untuk masing-masing pertemuan pada umumnya sama, yaitu di awal pembelajaran diperkenalkan tentang garis bilangan, demonstarsi penggunaan garis bilangan oleh guru, membagi siswa ke dalam beberapa kelompok, memberikan soal latihan untuk dikerjakan secara berkelompok dengan menggunakan garis bilangan secara bergantian, presentasi kelompok, pemberian soal untuk dikerjakan secara individu (tanpa garis bilangan), pemberian penghargaan, dan yang terakhir penarikan kesimpulan dan penutup.

Aktivitas yang berbeda hanya terletak pada aturan penggunaan garis bilangan disebabkan kesulitan siswa menggunakan garis bilangan, hal ini sesuai dengan penelitian Diezmann et al.22 yang menemukan bahwa siswa kesulitan menggunakan garis bilangan dan cenderung memperoleh hasil yang salah dalam perhitungan. Aturan penggunaan garis bilangan adalah positif diberi arti maju, bilangan negatif diberi arti mundur, ditambah berarti jalan terus, dan dikurang berarti balik kanan. Aturan semacam ini membuat siswa bingung antara maju dan jalan terus, selain itu mereka harus berbalik jika menemui pengurangan.

Dari berbagai kesulitan yang ditemui, perubahan aktivitas pada pertemuan dua diubah dan lebih diperjelas. Aturan penggunaan garis bilangan yang didemonstrasikan adalah langkah awal dimulai dari nol dengan posisi angka positif disebelah kanan dan dan angka negatif di sebelah kiri, bilangan positif berarti ke kanan, bilangan negatif berarti ke kiri, penjumlahan berarti maju, dan pengurangan berarti mundur. Perubahan aktivitas tersebut membuat siswa lebih mudah dalam menggunakan media, namun masih terdapat masalah yang harus dipikirkan peneliti, siswa terkadang bingung jika menemui operasi pengurangan dengan dua angka negatif karena mereka harus ke kiri sekaligus mundur, bingung kan?

Untuk itu, pada aktivitas tiga lintasan penggunaan media lebih diperjelas dengan langkah dimulai dari posisi nol (angka positif di sisi kanan dan angka negatif negatif di sisi kiri), bilangan positif berarti maju, bilangan negatif berarti mundur, penjumlahan berarti hadap kanan, dan pengurangan berarti hadap kiri. Akhirnya, perubahan aktivitas yang dilakukan dalam desain lintasan belajar tidak lagi membuat siswa bingung dalam menggunakan media.

22 Carmel M. Diezmann, Tom Lowrie, and Lindy A. Sugars, "Primary Students' Success on the Structured Number Line," Australian Primary Mathematics Classroom 15, no. 4 (2010): 24-28, https://eric.ed.gov/?id=EJ906683. 
Tabel 2. Perubahan Aktivitas penggunaan media Garis Bilangan

\begin{tabular}{|c|c|c|}
\hline Aktivitas 1 & Aktivitas 2 & Aktivitas 3 \\
\hline Positif berarti maju & $\begin{array}{l}\text { Langkah awal dimulai } \\
\text { dari } 0\end{array}$ & $\begin{array}{l}\text { Langkah dimulai dari } \\
\text { posisi } 0\end{array}$ \\
\hline Nega & $\begin{array}{l}\text { Posisi bilangan positif } \\
\text { di sebelah kanan dan } \\
\text { negatif di sebelah kiri }\end{array}$ & $\begin{array}{l}\text { Angka positif di kanan } \\
\text { dan angka negatif di kiri } \\
\text { siswa }\end{array}$ \\
\hline \multirow{2}{*}{$\begin{array}{l}\text { Tambah berarti jalan } \\
\text { terus }\end{array}$} & Positif berarti ke kanan & Positif berarti maju \\
\hline & Negatif berati ke kiri & Negatif berarti mundur \\
\hline \multirow[t]{2}{*}{$\begin{array}{l}\text { Kurang berarti balik } \\
\text { kanan }\end{array}$} & Tambah berarti maju & $\begin{array}{l}\text { Tambah berarti hadap } \\
\text { kanan }\end{array}$ \\
\hline & ang be & $\begin{array}{l}\text { Kurang berarti hadap } \\
\text { kiri }\end{array}$ \\
\hline
\end{tabular}

Dari hasil perubahan aktivitas dalam menggunakan garis bilangan tersebut abstraksi konsep yang diharapkan pada pertemuan tiga bisa dipahami siswa, yaitu penyamaan operasi penjumlahan terhadap bilangan negatif sama dengan pengurangan terhadap bilangan positif, selain itu siswa bisa menyelesaikan soal yang lebih kompleks dengan memuat beberapa operasi seperti "7 $+3-8+5-(-2)$ ". Dari hasil itulah peneliti menganggap bahwa aktivitas (aturan) penggunaan media garis bilangan pada pertemuan ketiga (Tabel 1 kolom ketiga) sebagai local instructional theory bagi siswa kelas IV di salah satu Madrasah Ibtidaiyah di Kota Tarakan.

\section{Kesimpulan}

Artikel ini memberikan gambaran tentang bagaimana peranan media garis bilangan dalam membangun pemahaman siswa pada pembelajaran operasi penjumlahan dan pengurangan bilangan bulat. Dari hasil penelitian, ditemui bahwa lintasan belajar yang dibuat telah membantu siswa memahami operasi penjumlahan dan pengurangan bilangan bulat. Begitu juga pemahaman siswa dari tahap konkret ke abstrak (formal/semi formal) telah berkembang, meskipun beberapa siswa secara individu masih salah dalam melakukan perhitungan.

Dari percobaan pengajaran sebanyak tiga kali, dikembangkan local instructional theory yang sesuai dengan kondisi siswa berupa aturan penggunaan media yang lebih mudah untuk dipraktikkan siswa yaitu; 1) titik awal siswa harus berada di angka 0 pada garis bilangan dengan bilang positif disebelah kiri dan negatif di sebelah kanan, 2) bilangan positif berarti maju, 3) bilangan negatif berarti mundur, 4) operasi penjumlahan berarti hadap kanan, dan 5) operasi pengurangan berarti hadap kiri. Penggunaan aturan media 
garis bilangan ini dapat diterapkan di sekolah lain untuk mengatasi sulitnya aturan penggunaan garis bilangan yang terkadang membingungkan guru.

\section{Ucapan Terimakasih}

Peneliti mengucapkan terima kasih kepada pimpinan dan guru di salah satu Madrasah Ibtidaiyah di Kota Tarakan yang telah mengizinkan dan membantu selama penelitian. Ucapan terima kasih juga kami haturkan kepada Lembaga Penelitian dan Pengabdian Masyarakat (LP2M) Universitas Borneo Tarakan dan semua pihak yang membantu sehingga penelitian ini dapat terselesaikan.

\section{Daftar Pustaka}

Akker, Jan Van Den, ed. Educational Design Research. 1st edition. London; New York: Routledge, 2006.

Almeida, Rut, and Alicia Bruno. "Strategies of Pre-Service Primary School Teachers for Solving Addition Problems with Negative Numbers." International Journal of Mathematical Education in Science and Technology 45, no. 5 (July 4, 2014): 719-37. https://doi.org/10.1080/0020739X.2013.877605.

Amir, Almira. "Pembelajaran Matematika SD Dengan Menggunakan Media Manipulatif." Forum Paedagogik 6, no. 01 (2014). https://doi.org/10.24952/paedagogik.v6i01.166.

Aras, Irianto. "Pengembangan Desain Pembelajaran Matematika Berbasis Teori Elaborasi Dengan Pendekatan Saintifik Pada Siswa Kelas X7 Madrasah Aliyah Negeri Pinrang." Masters, Pascasarjana, 2014. http://eprints.unm.ac.id/4723/.

Blair, Kristen Pilner, Miriam Rosenberg-Lee, Jessica M. Tsang, Daniel L. Schwartz, and Vinod Menon. "Beyond Natural Numbers: Negative Number Representation in Parietal Cortex." Frontiers in Human Neuroscience 6 (2012). https://doi.org/10.3389/fnhum.2012.00007.

Daro, Phil, Frederic A. Mosher, and Tom Corcoran. Learning Trajectories in Mathematics: A Foundation for Standards, Curriculum, Assessment, and Instruction. CPRE Research Report \# RR-68. Consortium for Policy Research in Education. Consortium for Policy Research in Education, 2011. https://eric.ed.gov/?id=ED519792.

Diezmann, Carmel M., Tom Lowrie, and Lindy A. Sugars. "Primary Students' Success on the Structured Number Line." Australian Primary Mathematics Classroom 15, no. 4 (2010): 24-28. https://eric.ed.gov/?id=EJ906683.

Dyson, Nancy I., Nancy C. Jordan, Jessica Rodrigues, Christina Barbieri, and Luke Rinne. "A Fraction Sense Intervention for Sixth Graders With or At Risk for Mathematics Difficulties." Remedial and Special Education 41, no. 4 (July 1 1, 2020): https://doi.org/10.1177/0741932518807139. 
Gravemeijer, Koeno, and Dolly van Eerde. "Design Research as a Means for Building a Knowledge Base for Teachers and Teaching in Mathematics Education." Elementary School Journal 109, no. 5 (May 2009): 510-24. https://doi.org/10.1086/596999.

Lubis, Elfi Lailan Syamita. "Penggunaan Media Garis Bilangan Untuk Meningkatkan Kemampuan Berhitung Bilangan Bulat Pada Siswa Kelas IV MIS Nurul Hasanah Lubuk Pakam Tahun Pelajaran 2016/2017." Medan: Universitas Negeri Medan, 2017.

Midgett, Carol W., and Susan K. Eddins. Special Section Math and Science Education Nctm's Principles and Standards for School Mathematics: Implications for Administrators, n.d.

Muhsetyo, Gatot. "Pembelajaran Matematika SD." Jakarta: Universitas Terbuka, 2009.

Muslimin, Muslimin, Ratu Ilma Indra Putri, and Somakim Somakim. "Desain Pembelajaran Pengurangan Bilangan Bulat Melalui Permainan Tradisional Congklak Berbasis Pendidikan Matematika Realistik Indonesia Di Kelas IV Sekolah Dasar." Kreano, Jurnal Matematika KreatifInovatif 3, no. 2 (December 1, 2012): 100-112. https://doi.org/10.15294/kreano.v3i2.2642.

Prahmana, Rully. Design Research (Teori Dan Implementasinya: Suatu Pengantar), 2017.

- - - "Pendesainan Pembelajaran Operasi Bilangan Menggunakan Permainan Tradisional Tepuk Bergambar Untuk Siswa Kelas III Sekolah Dasar (SD)," 2012. https://doi.org/10.13140/RG.2.2.33884.59529.

Santoso, Indah Syilvia. "Penggunaan Media Garis Bilangan Untukmeningkatkan Hasil Belajar Operasi Penjumlahan Dan Pengurangan Bilangan Bulat." Jurnal Penelitian Pendidikan Guru Sekolah Dasar 2, no. 3 (2014): 1-10.

Subanji, Subanji. Teori Kesalahan Konstruksi Konsep Dan Pemecahan Masalah Matematika, 2015.

Sukrila, Nikmatus. "Pengaruh Media Mistar Bilangan Terhadap Pemahaman Penjumlahan Bilangan Bulat Matematika Kelas IV MI Imami Kepanjen Malang." PhD Thesis, Universitas Islam Negeri Maulana Malik Ibrahim, 2015.

Sutrisno, Sutrisno. "Analisis Kesulitan Belajar Siswa Kelas Ii Pada Materi Penjumlahan Dan Pengurangan Bilangan." AKSIOMA : Jurnal Matematika Dan Pendidikan Matematika 6, no. 1/Maret (2015). https://doi.org/10.26877/aks.v6i1/Maret.862.

Zabeta, Mewa, Yusuf Hartono, and Ratu Ilma Indra Putri. “Desain Pembelajaran Materi Pecahan Menggunakan Pendekatan Pendidikan Matematika Realistik Indonesia (PMRI)." Beta: Jurnal Tadris Matematika 8, no. 1 (May 14, 2015): 86-99. https://jurnalbeta.ac.id/index.php/betaJTM/article/view/27. 